\title{
EVALUATION OF ZEFREH DOLOMITE (CENTRAL IRAN) FOR PRODUCTION OF MAGNESIUM VIA THE PIDGEON PROCESS
}

\author{
Behzad Mehrabi ${ }^{1}$, Masud Abdellatif ${ }^{2}$, and Fariborz Masoudi ${ }^{3}$ \\ ${ }^{1}$ Geology Department, Tehran Tarbiat Moallem University, Tehran, Iran \\ ${ }^{2}$ Mintek Corporate, Randburg, South Africa \\ ${ }^{3}$ Faculty of Earth Sciences, Shahid Beheshti University, Tehran, Iran
}

This study evaluates the production of magnesium metal from the Zefreh dolomite ore of Central Iran using the Pidgeon process. The investigation consisted of mineralogical and chemical characterization of the dolomite ore, calcining, chemical characterization, LOI (loss on ignition) determination, reduction tests on the calcined dolomite (dolime), using Iranian (Semnan) ferrosilicon and mineralogical, and chemical characterization of the reactants and products. Calcining of dolomite samples was carried out at approximately $1400^{\circ} \mathrm{C}$ in order to remove $\mathrm{CO}_{2}$, moisture, and other easily volatilized impurities. The dolime was then milled, along with ferrosilicon, thoroughly mixed, and briquetted. The briquettes were heated at $1125^{\circ} \mathrm{C}-1150^{\circ} \mathrm{C}$ and $500 \mathrm{~Pa}$ in a tube reactor for 10-12 hours to extract the magnesium. The ferrosilicon to dolime ratio was determined based on the chemical analyses of the two reactants, using as a guide, and Mintek's Pyrosim software package. Magnesium extraction varied with ferrosilicon addition and with the dolime used, and reach about $80 \%$ under optimal conditions. The levels of major impurities encountered in the magnesium crown were similar to those in the crude metal production.

Keywords: Mg metal, Pidgeon process, Semnan ferrosilicon, silicothemric, Zefreh dolomite

\section{INTRODUCTION}

The use of metallic magnesium is growing very rapidly, mainly for the production of light metal alloys, with applications in the aircraft and automotive industry, desulphurization of iron and steel, production of light weight mainly AlMg alloys, and some chemical applications (Habashi 1997). Approximately, 80\% of the worlds demand for magnesium is currently supplied by China and nearly $95 \%$ of the primary magnesium output of China is produced using the Pidgeon process primarily because of the low labor and energy costs as well as lax environmental controls (Ding and Zang 2001; Zang and Ding 2001; Cherubini, Raugei, and Ulgiati 2008).

There are two major industrial processes for magnesium metal production. The first involves thermal reduction of magnesium oxide, mainly from dolomite, with

Address correspondence to Behzad Mehrabi, Geology Department, Tarbiat Moallem University, No. 49, Mofateh Ave., Tehran, 15614, Iran. E-mail: mehrabi@tmu.ac.ir 
ferrosilicon known as silicothermic process. The second recovers magnesium chloride from raw material and converts it to metal through molten salt electrolysis.

Industrial thermal magnesium processes are based on the silicothermic reduction of calcined dolomite. The major processes for the thermal reduction of magnesium oxide in dolime are the Pidgeon, the Magnetherm, and the Bolzano process (Aghion and Golub 2006). The first commercial thermal process was the Pidgeon process (Pidgeon and Alexander 1944). The process was invented and developed in Canada by Dr L. M. Pidgeon, in the early 1940s. This batch process is carried out in gas- or coal-fired retorts and consists of the solid-state reaction of calcined dolomite $(\mathrm{CaO} \cdot \mathrm{MgO})$ and ferrosilicon at $13 \mathrm{~Pa}$ and $1150^{\circ} \mathrm{C}$. The magnesium vapor condenses and forms a solid crystalline "crown" at the water-cooled end of the retort. The process is heat-transfer limited, labor intensive, and involves long cycle times. It is used by Timminco at the original Pidgeon plant in Canada, and by Chinese magnesium producers. The production rate per retort is only $50 \mathrm{~kg}$ of magnesium per day.

The primary magnesium producing reactions in these thermal processes are between silicon, in the ferrosilicon $(75 \% \mathrm{Si}, 25 \% \mathrm{Fe})$, and the magnesium oxide in the dolime $(\mathrm{CaO} \cdot \mathrm{MgO})$ :

$$
\begin{gathered}
2(\mathrm{CaO} \cdot \mathrm{MgO})_{(\mathrm{s})}+(x \mathrm{Fe}) \mathrm{Si}_{(\mathrm{s})} \rightarrow 2 \mathrm{Mg}_{(\mathrm{s})}+2(\mathrm{CaO} \cdot \mathrm{SiO} 2)_{(\mathrm{s})}+\mathrm{Fe}_{(\mathrm{s})} \\
{\left[\Delta \mathrm{G}^{\circ}=600.6-0.269 \mathrm{~T}\left({ }^{\circ} \mathrm{K}\right), \mathrm{kJ}\right] \text { and }\left[\Delta \mathrm{H}^{\circ}=519.3-9.374 \ln \mathrm{T}\left({ }^{\circ} \mathrm{K}\right), \mathrm{kJ}\right]}
\end{gathered}
$$

Although there are huge amounts of dolomite ore, two ferrosilicon manufacturers, and relatively cheap energy, magnesium is not currently being produced in Iran. The Iranian market conditions favor the Pidgeon process, over the electrolytic process (Mehrabi 2005). Therefore, it is necessary to technically evaluate the dolomite resources that are available in Iran as a first step towards selecting the most suitable ore that can be used for the production of magnesium in the Pidgeon process. A careful review and sampling from major dolomite deposits in Iran (Mehrabi 2005) shows that the Zefreh dolomite is one of the most suitable dolomite deposits in Iran. It is also located in an area where the infrastructures exist for future development of a magnesium production plant (Mehrabi 2005; Mehrabi and Masoudi 2009).

In this study, we have characterized the Zefreh dolomite ore, and investigated the parameters affecting the silicothermic reduction of the Zefreh dolomite, using Semnan ferrosilicon, in the Pidgeon process.

\section{RAW MATERIAL}

The Zefreh dolomite mine is located $80 \mathrm{~km}$ northeast of the city of Isfahan in Central Iran. The annual dolomite production is $100 \mathrm{kt} / \mathrm{y}$ from the Permian and Triassic dolomitic units. In this study, samples were collected during two field seasons. The petrography of 60 samples, for dolomite and calcite, was carried out using a Zeiss Axioplan2 polarized light microscope after staining with alizarin red and potassium ferricyanide (Dickson 1965). Twenty-five samples were analyzed by WD-XRF (Wavelength dispersive X-ray fluorescence; Philips Magic-Pro), 10 samples by quantitative XRD (X-ray diffraction; Philips Expert-Pro) using Rietveld 
method, and four samples by DTA (differential thermal analysis)-TGA (thermogravimetric Analysis) (Netzsch STA 409PC). The run off mine and a composite sample (prepared from the collected samples) were analyzed by WD-XRF, and due to the similarity and comply with the industry standard, run off mine sample was selected as a representative sample for the calcining and reduction tests. The full analytical results are available from the corresponding author.

\section{EXPERIMENTAL}

In the Pidgeon process, magnesium metal is produced from calcined dolomite under vacuum at high temperatures using ferrosilicon as a reducing agent. In this process, the finely crushed dolomite is feed into kilns where it is calcined and then pulverized in a mill prior to mixing with finely ground ferrosilicon. After weighing and homogenizing, the calcined dolomite and ferrosilicon mixture is made into briquettes which are charged in a retort and placed in the reduction furnace. The reduction operation is a batch process releasing magnesium in vapor form, which condenses in the cooled end of the retort outside furnace wall. After removal from the furnace, the magnesium "crown" is removed from the sleeves.

The experimental assessment of the dolomite was carried out in the Mintek Laboratories in South Africa. The calcining of a representative dolomite sample from Zefreh was carried out in an induction furnace, consisting of a steel housing, alumina insulating bricks, and copper induction coils. A programmable temperature controller was used to adjust the heating rate and to control the temperature at the desired value for a certain period of time. A K-type thermocouple was used to measure the sample temperature and was positioned just above the magnesia crucible that contained the sample. Briquettes of known proportions of ferrosilicon and calcined dolomite were prepared using a press machine. Both reactants were milled to $-150 \mu \mathrm{m}$ in a conventional steel ball mill and mixed prior to briquetting.

The reduction tests were performed on the briquetted mixture using the retort setup shown in Figure 1. The assembly consisted of 316 stainless steel tube $(100 \mathrm{~mm}$ ID and $480 \mathrm{~mm}$ long). The tube (retort) was housed inside an electrically heated furnace (silicon carbide elements). The furnace is insulated with alumina bricks, and is provided with a programmable temperature controller.

The retort contained a gas outlet which was connected to a vacuum system, consisting of a vacuum pump, pressure transducer, pressure and temperature readouts, a shut-off valve, and an argon purge line. Two thermocouples were used to measure and control the temperature. The first was placed just outside the retort, while the second was located inside it to measure and record the reaction temperature. The pressure and temperature readings were recorded throughout the test using a data logger.

Calcining was carried out for 4 hours at $1400^{\circ} \mathrm{C}$ in order to drive off almost all of the carbon dioxide and moisture, as well as the easily volatilized components. After cooling, the mass loss was measured and samples were taken and analyzed (see Table 1). Calcining of dolomite can be broadly described as follows:

$$
\left(\mathrm{CaCO}_{3} \cdot \mathrm{MgCO}_{3}\right)_{(\mathrm{s})}+\text { Heat }=(\mathrm{CaO} \cdot \mathrm{MgO})_{(\mathrm{s})}+2 \mathrm{CO}_{2(\mathrm{~g})}
$$




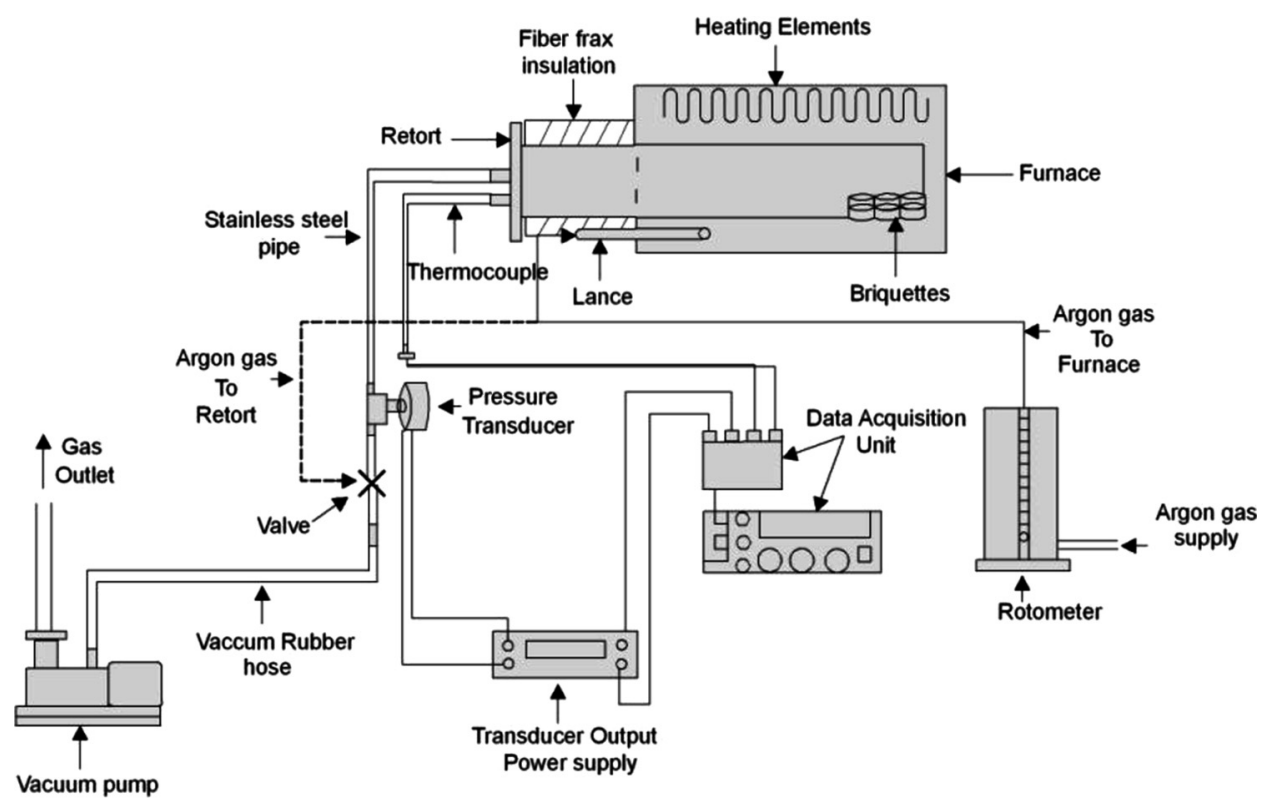

Figure 1 The setup used for experimental work in the Mintek Laboratory, South Africa.

$$
\left[\Delta \mathrm{G}^{\circ}=291.96-0.3313\left({ }^{\circ} \mathrm{K}\right), \mathrm{kJ}\right] \text { and }\left[\Delta \mathrm{H}^{\circ}=292.14-0.0187 \mathrm{~T}-2 \times 10^{-5} \mathrm{~T}^{2}\left({ }^{\circ} \mathrm{K}\right), \mathrm{kJ}\right]
$$

The calcining work was intended to prepare sufficient material for the reduction tests and was based on the DTA-TGA data, industrial practice, and Mintek's experience in this field.

Briquetting of Semnan ferrosilicon and Zefreh dolime involved accurately weighing predetermined amounts of each reactant, mixing, and pulverizing to $-150 \mu \mathrm{m}$ in a ball mill. Particle size analysis was carried out on the mixture. The best

Table 1. Chemical analyses of Zefreh dolomite, dolime, and Semnan ferrosilicon (\%)

\begin{tabular}{|c|c|c|c|c|c|c|c|}
\hline \multicolumn{8}{|c|}{ Dolomite } \\
\hline $\mathrm{MgO}$ & $\mathrm{CaO}$ & $\mathrm{Al}_{2} \mathrm{O}_{3}$ & $\mathrm{SiO}_{2}$ & $\mathrm{Fe}_{2} \mathrm{O}_{3}$ & $\mathrm{MnO}$ & $\mathrm{Ni}$ & LOI \\
\hline 20.60 & 31.10 & 0.09 & 0.41 & 0.53 & 0.06 & $<0.05$ & 46.90 \\
\hline \multicolumn{8}{|c|}{ Dolime } \\
\hline $\mathrm{MgO}$ & $\mathrm{CaO}$ & $\mathrm{Al}_{2} \mathrm{O}_{3}$ & $\mathrm{SiO}_{2}$ & $\mathrm{Fe}_{2} \mathrm{O}_{3}$ & $\mathrm{MnO}$ & $\mathrm{Ni}$ & LOI \\
\hline 37.75 & 58.28 & 0.24 & 0.83 & 1.16 & 0.09 & $<0.05$ & $<0.1$ \\
\hline \multicolumn{8}{|c|}{ Ferrosilicon } \\
\hline $\mathrm{Mg}$ & $\mathrm{Ca}^{*}$ & $\mathrm{Al}$ & $\mathrm{Si}$ & $\mathrm{Fe}$ & $\mathrm{Mn}$ & $\mathrm{Ni}^{*}$ & $\mathrm{C}$ \\
\hline 0.03 & $<20$ & 1.26 & 72.10 & 19.11 & 0.11 & 65 & 0.08 \\
\hline
\end{tabular}

*ppm. 
size distribution (for the Test 2 repeat onward) using standard sieve of +75 , $-75+53,-53+38$, and $-38 \mu \mathrm{m}$ was measured as $48.59 \%, 12.98 \%, 12.37 \%$, and $26.17 \%$ respectively. The mixture was then pressed to produce briquettes of $30 \mathrm{~mm}$ in diameter and $15 \mathrm{~mm}$ thick using a hydraulic press (pressure was set at $20 \mathrm{MPa}$ in Tests 1 and 2 and $30 \mathrm{MPa}$ in subsequent tests). The final mass of the briquettes was then recorded prior to being placed inside the retort.

After sealing, the retort was pressure-tested by applying vacuum of 500-700 Pa, switching off the vacuum pump, and monitoring the pressure readings. A leakage rate of $0.5 \mathrm{~cm}^{3} / \mathrm{min}$, or less, was considered to be acceptable to initiate the reduction test. Once the leak test was successful, the retort was heated to $700^{\circ} \mathrm{C}$ over a 2-hour period, followed by a degassing period of 2 hours $\left(\right.$ at $700^{\circ} \mathrm{C}$ ) in order to drive off any residual moisture and/or carbon dioxide that may have been present in the reactants. For a short period, the retort pressure would increase slowly by $100-300 \mathrm{~Pa}$ before dropping back to 500-700 Pa.

The temperature was then increased to $1150^{\circ} \mathrm{C}$ over a 2-hour period and the reduction reaction allowed continuing for about 8 hours. The pressure tended to increase slightly when the temperature approached $1100^{\circ} \mathrm{C}-1150^{\circ} \mathrm{C}$. This pressure change was similar to that observed during the degassing period and lasted for only a few minutes.

The furnace power was then switched off (as well the vacuum pump), and the system was brought up to just above atmospheric pressure by introducing argon into the retort. Finally, the facility was allowed to cool down to near room temperature before opening the retort and collecting the products. Both the mass of briquette residue (slag) and magnesium crown were measured, and clean samples were taken for chemical analysis. In most tests, a small amount of powdery material formed on the side walls of the retort (less than 1 gram), particularly near the flange area. This material was recovered, weighed, and analyzed separately.

In addition to the commissioning test, three tests were carried out in order to evaluate the effect of the $\mathrm{FeSi} /$ dolime ratio, grinding rate, and briquette making conditions on the extraction of magnesium.

\section{RESULT AND DISCUSSIONS}

The chemical composition of Semnan ferrosilicon and Zefreh dolomite sample is shown in Table 1. The ferrosilicon contains about $72 \%$ silicon and $19 \%$ iron, whereas the normal composition of the material used for magnesium production contains $75 \% \mathrm{Si}$, with the balance being mostly $\mathrm{Fe}$. The products of each reduction test consisted of three distinct phases: magnesium crown that condensed mainly on the side at the end of the retort, as this is the coldest section of the setup; a white deposit that tended to stick to the side walls of the retort (about $1 \mathrm{~g}$ per test); and the reacted briquettes. Each product was carefully removed from the retort, weighed, and analyzed.

The briquette residues produced in Tests 1 and 2 (as well as the commissioning Test) were relatively high in $\mathrm{MgO}$ (see Table 2). This is believed to be related, in part, to the milling and mixing of the reactants and the pressing of the briquettes in relation to the particle size and the $\mathrm{FeSi} /$ dolime contact surface area. The surface contact area between FeSi and dolime particles has a major impact on the reaction 
Table 2. Chemical analyses of briquette residue and crown magnesium

\begin{tabular}{lcccccccccc}
\hline & \multicolumn{7}{c}{ Briquette residue } \\
\cline { 2 - 11 } & $\mathrm{MgO}$ & $\mathrm{CaO}$ & $\mathrm{Al}_{2} \mathrm{O}_{3}$ & $\mathrm{SiO}_{2}$ & $\mathrm{FeO}$ & $\mathrm{MnO}$ & $\mathrm{TiO}_{2}$ & $\mathrm{Cr}_{2} \mathrm{O}_{3}$ & $\mathrm{Co}$ & $\mathrm{Ni}$ \\
\hline Comm. & 17.85 & 47.45 & 2.45 & 26.20 & 7.70 & 0.20 & 0.11 & 1.09 & $<0.05$ & 0.24 \\
Test 1 & 12.20 & 49.50 & 0.87 & 35.10 & 6.86 & 0.38 & 0.18 & 0.31 & $<0.05$ & $<0.05$ \\
Test 2 & 13.00 & 51.54 & 0.65 & 29.80 & 6.55 & 0.07 & 0.05 & $<0.01$ & $<0.05$ & $<0.05$ \\
Test 2R & 9.50 & 52.22 & 0.96 & 27.64 & 7.13 & 0.13 & 0.08 & $<0.01$ & $<0.05$ & $<0.05$ \\
Test 3 & 7.81 & 52.80 & 0.94 & 35.55 & 9.38 & 0.11 & 0.03 & $<0.01$ & $<0.05$ & $<0.05$ \\
Test 3R & 7.63 & 54.04 & 1.02 & 37.29 & 7.65 & 0.14 & 0.10 & $<0.01$ & $<0.05$ & $<0.05$ \\
\hline & & & & & $\mathrm{Magnesium}$ crown & & & & \\
& $\mathrm{Mg}$ & $\mathrm{Ca}$ & $\mathrm{Al}$ & $\mathrm{Si}$ & $\mathrm{Fe}$ & $\mathrm{Mn}$ & $\mathrm{Ti}$ & $\mathrm{Cr}$ & $\mathrm{Co}$ & $\mathrm{Ni}$ \\
\hline Comm. & 75.74 & 0.74 & 0.25 & 0.24 & 0.56 & 0.02 & 0.03 & $<0.05$ & 0.02 & 0.12 \\
Test 1 & 97.15 & 0.77 & 0.07 & $<0.20$ & $<0.50$ & 0.03 & 0.02 & $<0.05$ & 0.02 & 0.04 \\
Test 2 & 100 & 0.26 & $<0.05$ & $<0.20$ & $<0.50$ & $<0.01$ & 0.02 & $<0.05$ & 0.01 & 0.03 \\
Test 2R & 97.50 & 2.72 & $<0.05$ & $<0.20$ & $<0.50$ & $<0.01$ & $<0.01$ & $<0.05$ & $<0.01$ & 0.03 \\
Test 3 & 95.23 & 2.39 & 0.30 & 0.66 & $<0.50$ & 0.07 & $<0.01$ & $<0.05$ & $<0.01$ & 0.03 \\
Test 3R & 97.05 & 2.23 & $<0.05$ & $<0.20$ & $<0.50$ & $<0.01$ & $<0.01$ & $<0.05$ & $<0.01$ & 0.03 \\
\hline
\end{tabular}

Note: Comm., commissioning test; $\mathrm{R}$, repeat test.

(Morsi et al. 2002), as magnesium reduction under the experimental conditions used is a solid-solid reaction. When the contact area is relatively small (large particles and/or inadequate mixing and pressing), the reduction reaction does not proceed to completion. In addition, the initial contact area can easily be blocked by the reaction products, leading to a lower magnesium extraction efficiency and hence a higher $\mathrm{MgO}$ in the resulting briquette residue.

Further milling and mixing (Test 2 repeat onward) and briquetting at higher pressures resulted in a lower $\mathrm{MgO}$ content in the briquette residue, as can be seen in the results of Test 2 and Test 2 repeat ( $2 \mathrm{R}$ ). These two tests used $19.8 \% \mathrm{FeSi}$ addition. Using Mintek's Pyrosym software (Jones 1987) and experimental data, the $\mathrm{FeSi}$ addition was increased to about $21 \%$ (Test 3 and $3 \mathrm{R}$ ) leading to a further reduction of the $\mathrm{MgO}$ content in the briquette residue which reached about $7.6 \%$. Notice that in Table 2, both iron and silicon in the briquette residue are expressed as oxides. This is not entirely true, as most of the iron and unreacted silicon tend to form a FeSi alloy (residual ferrosilicon). Other metals ( $\mathrm{Mn}, \mathrm{Ni}$, etc.) tend to concentrate in this FeSi product.

Chemical analysis of samples taken from the condensed magnesium (referred to as crown) suggests that impurity levels are not significantly different from those contained in crude magnesium produced either in the Magnetherm or Mintek thermal magnesium processes (Abdellatif 2006a, 2006b). In Tests 1 and 2 where dolime was used with a FeSi addition of $18.0 \%$ and $19.8 \%$, the purest crown product was produced (see Table 2).

In subsequent tests, the crown tended to contain higher levels of calcium, and in some cases silicon. In these tests, the ferrosilicon addition was $21 \%$ of the dolime mass, an addition level that could have contributed to increased volatilization of calcium and silicon (mostly as $\mathrm{SiO}$ ). 
Table 3. Magnesium extraction and condensation efficiency

\begin{tabular}{lcc}
\hline Test no. & Extraction (\%) & Condensation efficiency (\%) \\
\hline Comm. & 50.78 & NA \\
Test 1 & 67.12 & 60.3 \\
Test 2 & 65.01 & 99.3 \\
Test 2R & 75.02 & 101.3 \\
Test 3 & 79.47 & 97.0 \\
Test 3R & 79.75 & 97.5 \\
\hline
\end{tabular}

Note: Comm., commissioning test; $\mathrm{R}$, repeat test.

Nickel analysis may have been affected by the use of a nickel grease to ease the tightening and loosening of the bolts of the flange. Iron, nickel, manganese, and chromium could have entered into the metal from the retort itself where scaling was observed in certain tests.

Magnesium extraction was calculated based on the mass of briquette residue and its magnesium content (see Table 3) and is defined as follows:

(Magnesium in feed - Magnesium in briquette residue)/Magnesium in feed $\times(100 \%)$, where:

Magnesium in feed $=$ Dolime mass $\times$ Mg analysis in dolime Magnesium in briquette residue $=$ Briquette residue mass $\times$

$\mathrm{Mg}$ analysis in Briquette residue mass

The magnesium extraction efficiency was relatively low in Tests 1 and 2, where the ferrosilicon addition was $18 \%$ and $19.8 \%$, respectively. This may be due to various factors including the particle size of the milled reactants and the briquetting conditions. Therefore, for the subsequent tests, the dolime and ferrosilicon were milled further and briquetted at higher pressure in order to increase the surface contact between ferrosilicon and the dolime particles. Doing so resulted in higher extraction

Table 4. Overall mass balance

\begin{tabular}{|c|c|c|c|c|c|c|c|c|}
\hline \multicolumn{4}{|c|}{ Materials in $(\mathrm{g})$} & \multicolumn{4}{|c|}{ Materials out (g) } & \multirow[b]{2}{*}{ Acc. $(\%)$} \\
\hline Test no. & Dolime & $\mathrm{FeSi}$ & Total & $\mathrm{Mg}$ crown & B. res. & $\mathrm{MgO}$ & Total & \\
\hline Comm. & 100.00 & 18.00 & 118.00 & 7.75 & 126.30 & 0.00 & 134.05 & 113.60 \\
\hline Test 1 & 167.88 & 30.62 & 198.50 & 16.36 & 174.70 & 0.83 & 191.89 & 96.67 \\
\hline Test 2 & 167.00 & 33.00 & 200.00 & 24.92 & 169.62 & 0.43 & 194.97 & 97.49 \\
\hline Test $2 \mathrm{R}$ & 156.98 & 31.02 & 188.00 & 28.22 & 157.80 & 0.67 & 186.69 & 99.30 \\
\hline Test 3 & 166.58 & 35.82 & 202.40 & 30.70 & 165.30 & 0.00 & 196.00 & 96.84 \\
\hline Test 3R & 168.43 & 35.37 & 208.80 & 32.50 & 168.70 & 0.62 & 201.82 & 96.66 \\
\hline
\end{tabular}

Note: Comm., commissioning test; R, repeat test; Acc., accountability. 


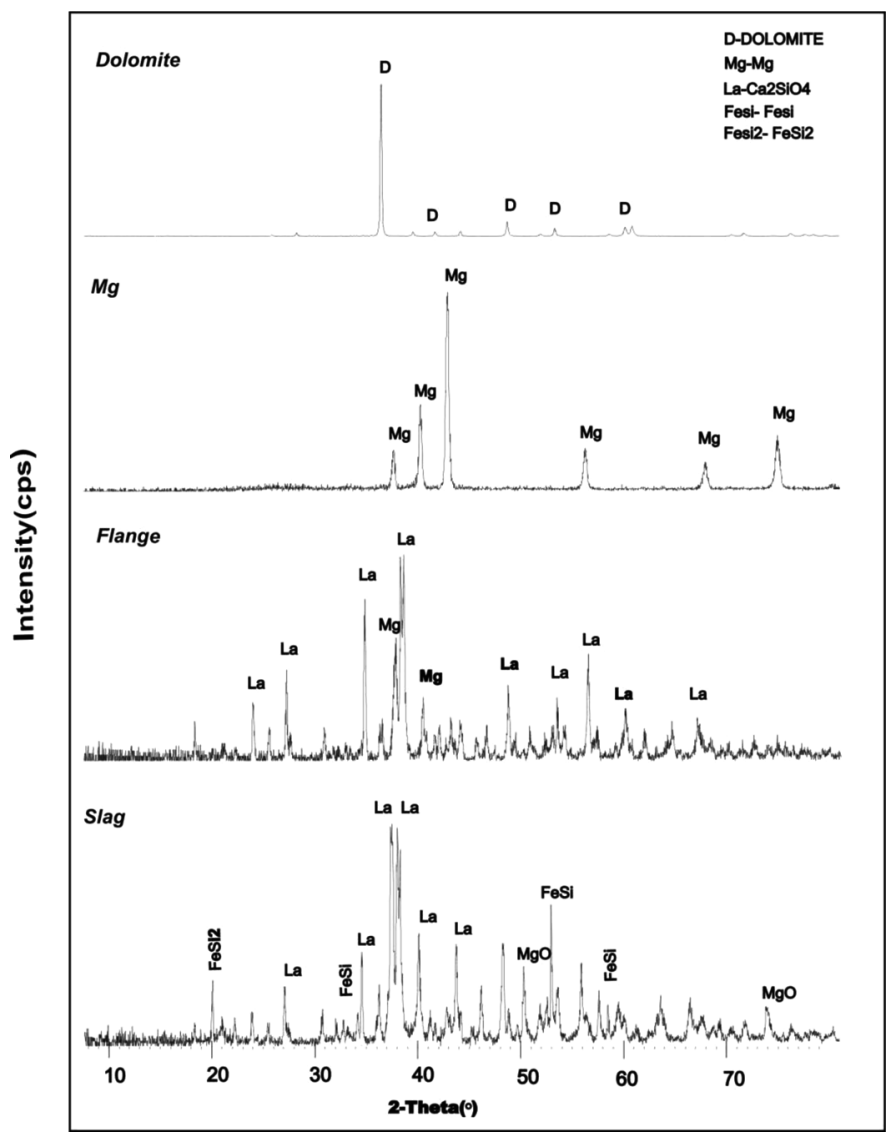

Figure 2 XRD pattern of Zefreh dolomite, Mg crown, white precipitated material inside the flange, and briquette residue (slag).
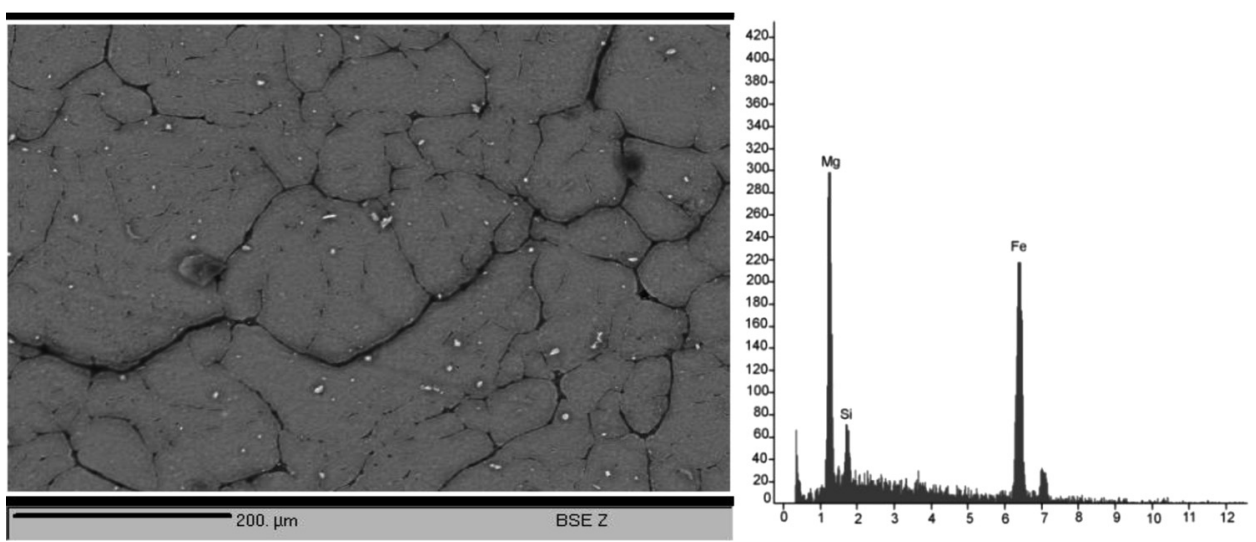

Figure 3 BSE image of Mg crown and the chemical composition of the white area (EDAX). The Mg content is from $\mathrm{Mg}$ crown and probably the $\mathrm{Fe}$ and $\mathrm{Si}$ are impurities. In some of the point analysis, Ca was recorded. 
efficiency in the repetition of Test 2 . Increasing the ferrosilicon content to $21 \%$ resulted in a magnesium extraction efficiency of about $80 \%$ in Test 3.

The last column in Table 3 is an estimate of the magnesium condensation efficiency. Although the data are very preliminary as no attempt was made to optimize the condensation efficiency, the calculated values are very high for all the tests. It should be noted that the measured flange temperature where most of the condensation took place was about $300^{\circ} \mathrm{C}$. Magnesium condensation was defined as follows:

$\mathrm{Mg}$ condensation $=$ Magnesium in the crown $/$ Magnesium extracted $\times 100 \%$

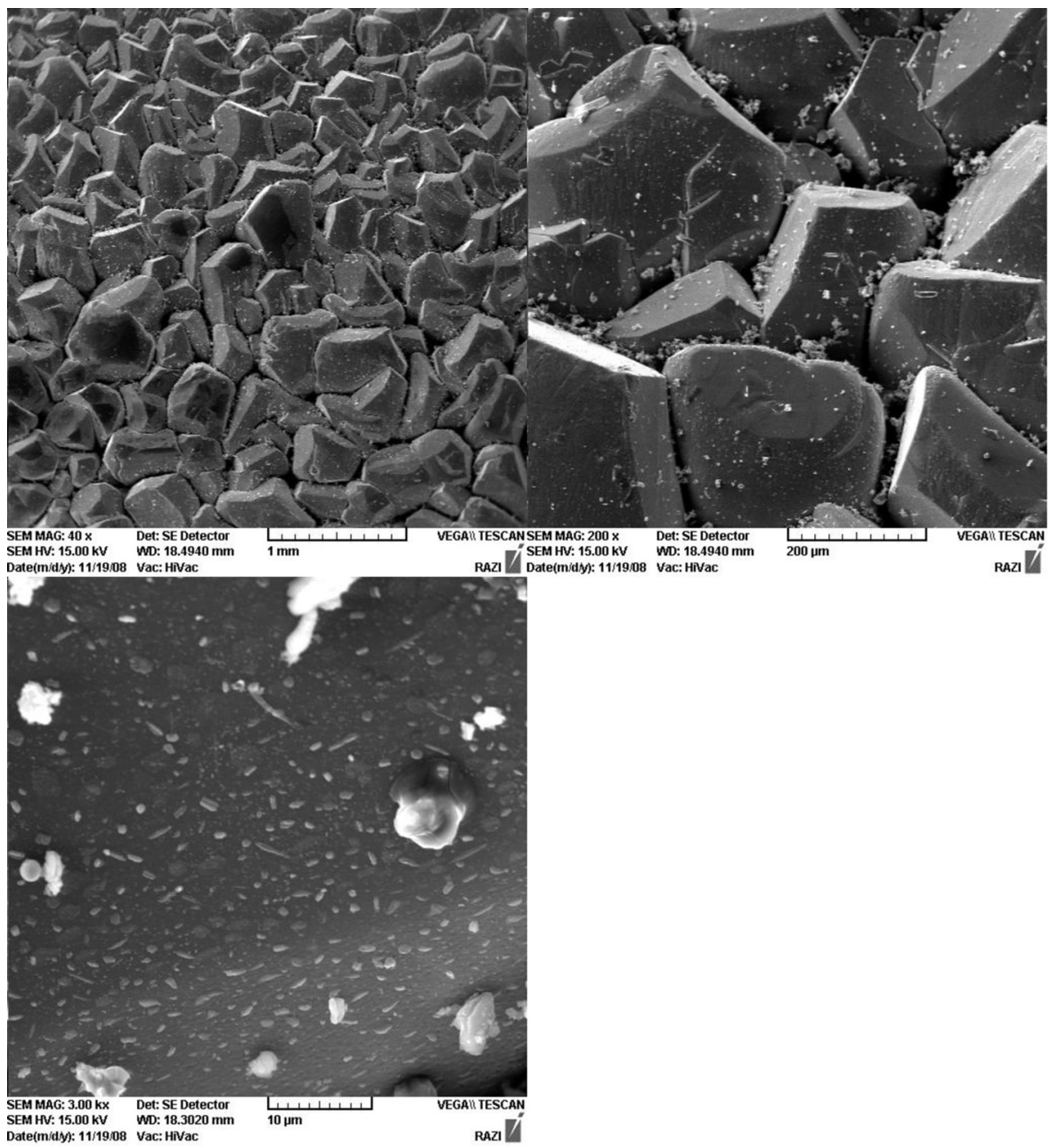

Figure 4 SEM image of crown magnesium showing a small deposition of a calcium compound. The image has been acquired few weeks after reduction, and it seems that calcium has been blossomed. 
As previously stated, increased ferrosilicon, addition relative to dolime, may lead to higher levels of impurities in the condensed magnesium. Therefore, a compromise between magnesium extraction and metal refining requirement is usually sought based upon economic considerations.

As shown in Table 4, the overall mass recovery was consistently high and ranged from about $97.0 \%$ to $99.3 \%$ during the tests, except for the commissioning run.

The samples of crown magnesium, briquette residue, and the white deposit on the side of retort were analyzed by XRD (see Figure 2). The crown magnesium was studied by Cameca SX-100 EPMA (see Figure 3) and TESCAN SEM (see Figure 4). The area covered by crystalline magnesium is pure, while in poorly crystalline areas, there are traces of calcium, silica, and iron. On the surface of magnesium crystals, there were small deposits of calcium compound which was also found inside the crystals (back scattered electron (BSE) image on polished sample).

\section{CONCLUSION}

Chemical and mineralogical analysis of the Zefreh dolomite sample indicates that it is suitable for magnesium production in a thermal process (such as Pidgeon). Test works using the Zefreh calcined dolomite and its reduction by Semnan ferrosilicon in the Pidgeon process were carried out in $500 \mathrm{~Pa}, 1150^{\circ} \mathrm{C}$, for $10-12$ hours, and yield a suitable magnesium metal in terms of magnesium extraction and crude magnesium metal quality. In spite of the low Si content of the Semnan ferrosilicon $(72 \%)$ compared with the industry standard $(75 \%)$ and with no addition of fluorite as a catalyst, magnesium extraction efficiency was determined as $79.75 \%$.

Changing the ratio of Zefreh calcined dolomite to the FeSi addition allowed the extraction efficiency to be optimized. Reducing the particle size to $-150 \mu \mathrm{m}$, increasing ferrosilicon content to $21 \%$, and using a briquetting pressure of $30 \mathrm{MPa}$ resulted in a magnesium extraction of $79.75 \%$ and condensation efficiency of $97.5 \%$, although it does produce higher levels of impurities in the crown magnesium. The temperature of cool end of retort, during condensation, was set about $300^{\circ} \mathrm{C}$ which resulted in a very high condensation efficiency for all the tests. The levels of major impurities in the magnesium crown were similar to those in the crude metal production.

\section{ACKNOWLEDGMENTS}

Authors wish to thank Dr. David Banks, School of Earth and Environment, Leeds University, for reading and improving the manuscript. We would like to thank Prof. S. K. Kawatra and five anonymous reviewers whose constructive comments significantly improved the manuscript. This work was financially supported by Iranian Ministry of Industries and Mines (Makta grant) and Tehran Tarbiat Moallem University research vice-chancellor.

\section{REFERENCES}

Abdellatif, M., 2006a, "Pilot plant demonstration of the Mintek Thermal Magnesium Process." In Proceedings of the International Symposium on Magnesium Technology in 
the Global Age, (M. O. Pekguleryuz and L. W. F. Mackenzie, Eds.), Conference of the Metallurgist, Montreal, Quebec, Canada, Met. Soc. of CIMM, pp. 67-80.

Abdellatif, M., 2006b, "Refining testwork on crude magnesium produced in the Mintek Thermal Magnesium Process." In Southern African Pyrometallurgy 2006 International Conference, (R. T. Jones, Ed.) Johannesburg, South Africa: SAIMM, pp. 343-355.

Aghion, E. and Golub, G., 2006, "Production technologies of magnesium." In Magnesium Technology: Metallurgy, Design, Applications, (H. E. Friedrich and B. L. Mordike, Eds.), Heidelberg: Springer, pp. 29-62.

Cherubini, F., Raugei, M., and Ulgiati, S., 2008, "LCA of magnesium production; technological overview and worldwide estimation of environmental burdens." Resources, Conservation and Recycling, 52, pp. 1093-1100.

Dickson, J. A. D., 1965, "A modified technique for carbonates in thin section." Nature, 205(4971), p. 587.

Ding, W. and Zang, J., 2001, "The Pidgeon process in China," 3rd Annual Australasian Magnesium Conference, Sydney, Australia, pp. 7.

Habashi, F., 1997, Handbook of Extractive Metallurgy, Vol. 2, Weinheim: Wiley.

Jones, R. T., 1987, “Computer Simulation of Pyrometallurgical Processes.” In Proceedings of the Twentieth International Symposium on the Application of Mathematics and Computers in the Minerals Industries, Vol. 2. Metallurgy, Johannesburg, SAIMM, p. 265.

Mehrabi, B., 2005, "The Most Suitable Technology for Magnesium Production from Mg-bearing Minerals in Iran" (in Persian). University of Industries and Mines, Makta1324-MIM grant, Final Report.

Mehrabi, B. and Masoudi, F., 2009, "Magnesium Metal Production Using Lloyd Pidgeon Process" (in Persian). University of Industries and Mines, Makta 17238-MIM grant, Final Report.

Morsi, I. M., El-Barawy, K. A., Morsi, M. B., and Abdel-Gawad, S. R., 2002, "Silicothermic reduction of dolomite ore under inert atmosphere." Canadian Metallurgical Quarterly, 41(1), pp. 15-28.

Pidgeon, L. M. and Alexander, W. A., 1944, "Thermal production of magnesium--pilot plant studies on the retort ferrosilicon process." Transactions AIME, 159, pp. 315-352.

Zang, J. and Ding, W., 2001, "The Pidgeon process in China and its future," Magnesium Technology, Warrendale, PA: Minerals, Metals, and Materials Society, pp. 7-10. 